\title{
Biogeographic distribution of diversity and size- structure of organic-walled dinoflagellate cysts
}

\author{
Bingzhang Chen ${ }^{1,3}$, Andrew J. Irwin ${ }^{2}$, Zoe V. Finkel ${ }^{1, *}$ \\ ${ }^{1}$ Environmental Science Program, Mount Allison University, Sackville, New Brunswick E4L 1A7, Canada \\ ${ }^{2}$ Department of Mathematics and Computer Science, Mount Allison University, Sackville, New Brunswick E4L 1A6, Canada \\ ${ }^{3}$ Present address: State Key Laboratory of Marine Environmental Science, Xiamen University, Xiamen, Fujian 361005, PR China
}

\begin{abstract}
Global biogeographic patterns and environmental correlates of diversity and size structure of extant marine organic dinoflagellate cysts were determined. Dinoflagellate cyst diversity, like that of many other terrestrial and marine groups, is lowest at the poles and higher at lower latitudes. Temperature is responsible for much of the positive correlation between dinoflagellate cyst diversity and latitude. In contrast, the most obvious correlate with the median size of dinoflagellate cysts is the depth of the water column, especially in warm-water regions, perhaps due to changes in mixing regime and the advantages associated with the lower sinking rates and lower nutrient requirements of smaller species in offshore waters. The unique biogeographic pattern in dinoflagellate cyst diversity may reflect the unique physiological features of dinoflagellates: preference for warm, stable water columns, slower inherent growth rates, and their ability to act as mixotrophs or heterotrophs. Dinoflagellates tend to be 'gleaners', slow-growers adapted to oligotrophic conditions and less sensitive to inorganic nutrient supply, as compared to inorganic resource 'opportunists' with high growth rates, such as diatoms. These ecophysiological differences between dinoflagellates and other functional groups, such as diatoms and coccolithophores, may account for the major differences in the biogeographic and latitudinal diversity gradients between these groups.
\end{abstract}

KEY WORDS: Dinoflagellate cysts $\cdot$ Biogeography $\cdot$ Diversity $\cdot$ Size

\section{INTRODUCTION}

Diversity and size structure of organisms in communities are influenced by environmental conditions, and have the capacity to alter the structure and function of food webs and the biogeochemical cycling of key elements (Hutchinson 1959, Brown et al. 2004, Finkel et al. 2007, 2010). Large-scale patterns of biodiversity and community size structure can provide insights into the underlying mechanisms that shape ecosystem structure and function (Brown 1995, Rosenzweig 1995, Gaston \& Blackburn 2000, Li 2002, Allen \& Gillooly 2006). Currently, it is unclear what factors control plankton richness and size structure in the sea, whether there are differences between taxonomic groups, whether environmental selection on species affects biogeographic patterns in species richness and size structure, and, in turn, whether these biogeographic patterns reflect peculiar selective environmental conditions.

Higher species diversity at low latitudes have been predicted for marine phytoplankton (Barton et al. 2010) and have been observed for marine bacterioplankton (Fuhrman et al. 2008), coccolithophorids (Cermeño et al. 2008a), tintinnid ciliates (Dolan et al. 2006), and copepods (Woodd-Walker et al. 2002), but not for diatoms or mixed phytoplankton assemblages (Cermeño et al. 2008a,b). There are some general trends in phytoplankton size structure in response to temperature, light, and nutrient concentration. For example, average phytoplankton cell size within communities tends to increase with nutrient availability and decrease with in- 
creasing temperatures, but exceptions are not uncommon (Li 2002, Finkel et al. 2009, Kostadinov et al. 2009, Mei et al. 2009, Chen \& Liu 2010). Observational data on the biogeographic distributions of different plankton functional groups and their environmental correlates can be used to test hypotheses about the controls on community diversity and size structure and improve predictions for how future environmental and climate change may alter the biogeographic distributions of these important organisms. In the present paper, we have quantified the global biogeographic patterns and environmental correlates of diversity and size structure of extant marine organic dinoflagellate cyst communities, for which a large data set of recent dinoflagellate cyst abundances from core tops has been made publicly available (Marret \& Zonneveld 2003, Radi \& de Vernal 2008). As these samples were all collected from surface sediments, the data set is a compilation of present-day distributional patterns of marine extant organic dinoflagellate cysts (Marret \& Zonneveld 2003). Traditionally, correlations between modern environmental conditions and the dinoflagellate cyst community structure from core tops have been applied to down-core communities to reconstruct paleoenvironmental conditions; here we focus on modern environmental correlates related to dinoflagellate community size structure and diversity.

Dinoflagellates are important primary producers, and some also play a significant role as herbivores in the microbial food web (Margalef 1978, Azam et al. 1983, Hansen 1992, Sherr \& Sherr 2007). Dinoflagellates are motile and have some unique physiological features compared to other plankton functional groups, including a preference for water stability, an ability to live as mixotrophs or heterotrophs, and the ability of some species to form cysts (Taylor 1987, Smayda 1997, Litchman 2007). Approximately 20\% dinoflagellate species can form resting cysts as part of their life cycle (Taylor 1987), which can act to protect the species under unfavorable conditions and seed new dinoflagellate communities under favorable conditions (Anderson \& Wall 1978, Lewis et al. 1999). Cyst formation may be triggered by environmental stress such as nutrient depletion in laboratory cultures (Anderson et al. 1985a). In the field, however, induction of sexuality and encystment of dinoflagellates has also been associated with optimal temperature, light, and nutrient conditions, as well as other endogenous factors (Anderson et al. 1985a, Kremp \& Heiskanen 1999). Cyst formation in dinoflagellates may be a survival strategy to minimize lateral dispersal into unfavorable regions as opposed to avoidance of environmental stress (Smetacek 1985). We hypothesize that the unique eco-physiological features of the cystforming dinoflagellates may result in distributional patterns different from those of other functional groups with distinctly different physiological traits and tradeoffs.

With the goal of identifying the primary environmental controls of diversity and size structure of plankton communities, we address the following specific questions: (1) What are the primary environmental correlates of dinoflagellate cyst diversity and size structure? (2) Do the large-scale distributional patterns in richness and community size structure of organic cyst-forming dinoflagellates differ from those of other phytoplankton groups with different ecophysiological traits? (3) If there are differences, what are the likely mechanisms generating such differences? Our approach was to map the community diversity and size structure of dinoflagellate cysts and determine their statistical relationships to the environmental variables latitude, temperature, nutrient concentrations, and water depth. These results should provide insight into the environmental conditions that support dinoflagellate diversity in the water column and cause encystment.

\section{MATERIALS AND METHODS}

We analyzed a global database of extant organic dinoflagellate cysts from a number of literature sources covering the Arctic Ocean, sub-Arctic, North Atlantic and adjacent areas, and eastern North Pacific (Radi \& de Vernal 2008 [1171 samples]), Benguela upwelling system (Zonneveld et al. 2001 [41 samples], Holzwarth et al. 2007 [54 samples]), tropical African margin in the eastern Atlantic (Marret 1994 [46 samples], Marret \& Zonneveld 2003 [39 samples]), western equatorial Atlantic (Vink et al. 2000 [34 samples]), Atlantic sector of the Southern Ocean (Esper \& Zonneveld 2002 [32 samples]), Antarctic waters near the Falkland Islands (Harland et al. 1998 [14 samples]), southern Indian and Pacific (Marret \& de Vernal 1997 [67 samples]), and mid-African area in the eastern Atlantic influenced by the Congo River plume (Dale et al. 2002 [34 samples]). Calcareous or siliceous cysts were excluded because they may reflect separate functional groups responding differently to environmental conditions, including different nutrient requirements (e.g. only the siliceous forms need silicate) and resistance to decay. The final data set consisted of 1532 samples of organic-walled dinoflagellate cysts collected from surface sediments (upper centimeter), representing 10 to 1000 yr, depending on sedimentation rates and bioturbation (Fig. 1; Marret \& Zonneveld 2003, Radi \& de Vernal 2008). All species in the study are extant. The samples were treated and examined using comparable up-to-date methodology to assure consistency (Marret \& Zonneveld 2003, Radi \& de Vernal 2008). An excellent summary of much of this data set, including background 


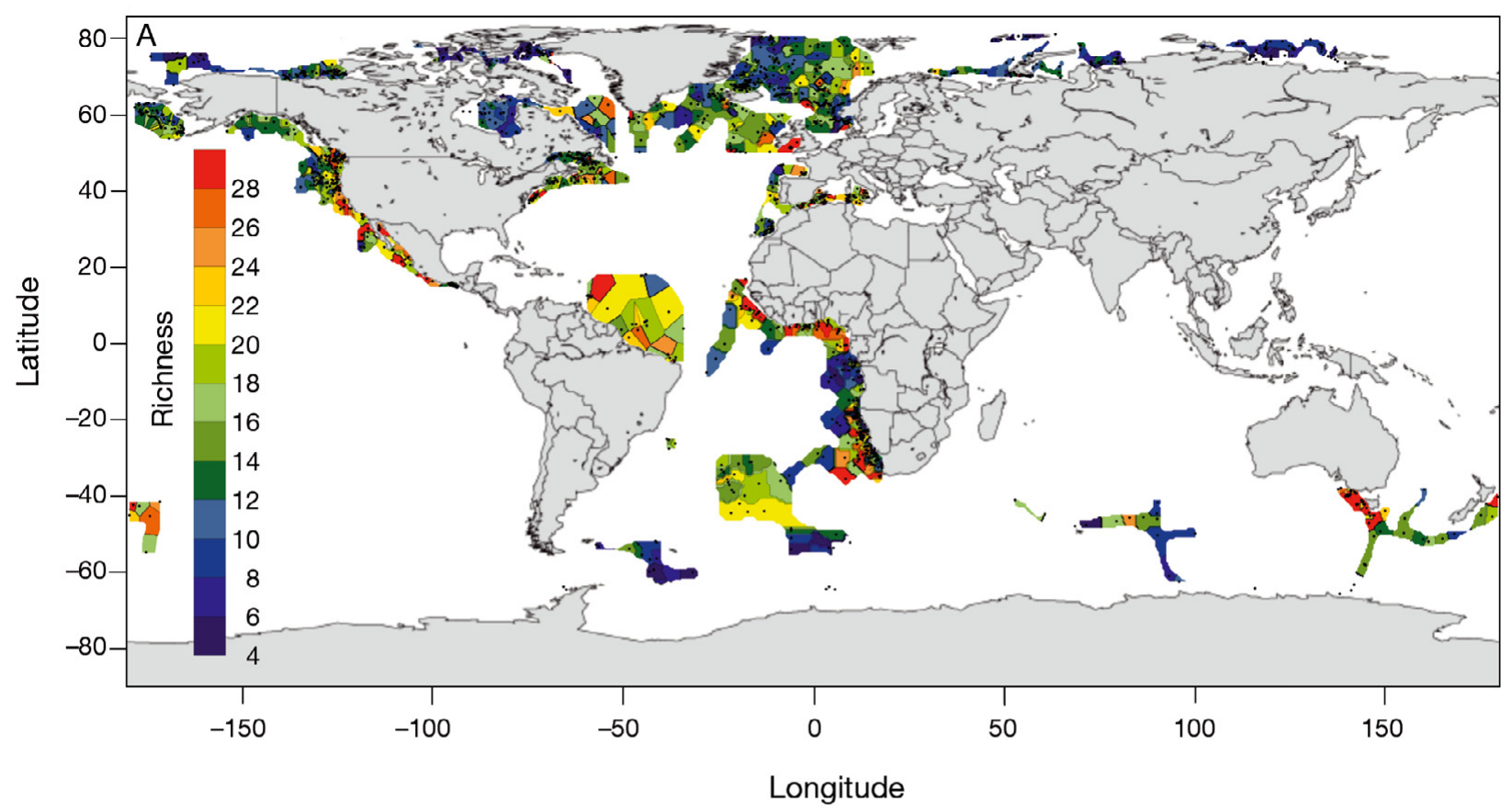

Fig. 1. (A) Species richness of organic-walled dinoflagellate cysts at sampling locations in surface sediments. (B) Dinoflagellate cyst richness versus latitude, with loess smoothing lines (solid lines) and 95\% confidential intervals (dashed lines) shown. Red and blue lines represent species richness of coccolithophorids and diatoms, respectively, digitized from Cermeño et al. (2008a)

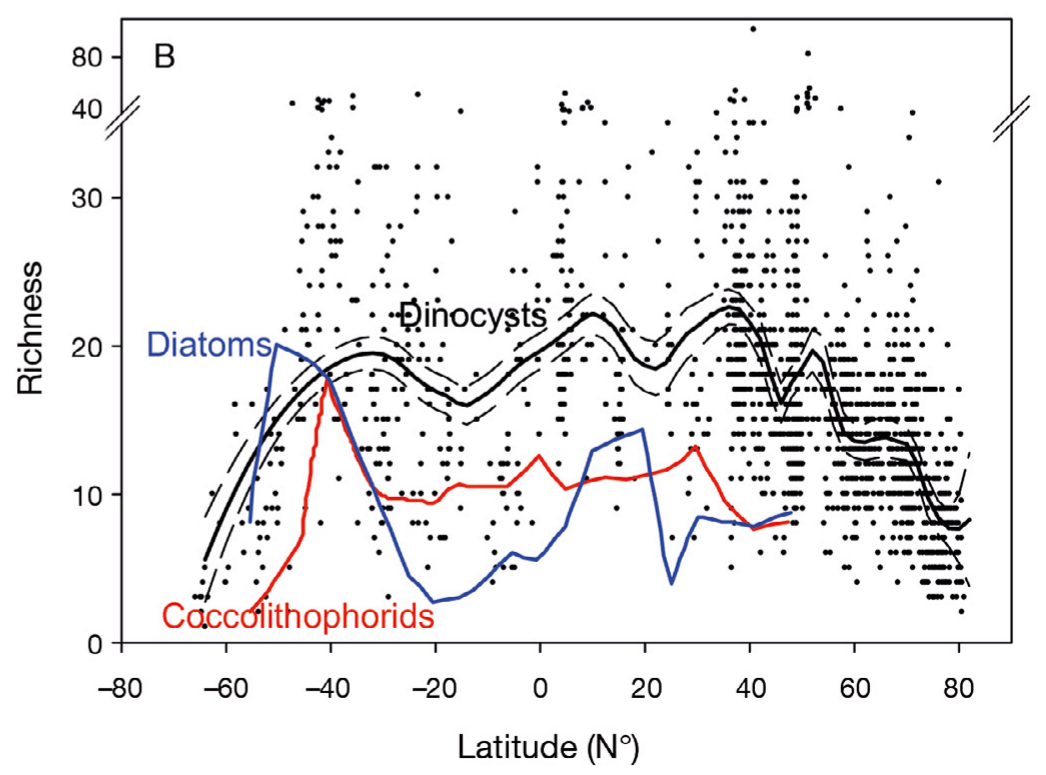

oceanographic information and descriptions of the species, is provided by Marret \& Zonneveld (2003).

Species diversity of the cyst assemblages is calculated as species richness

$$
S=S_{\mathrm{obs}}+\frac{a(a-1)}{2(b+1)}
$$

(Colwell 2005), in which $S_{\text {obs }}$ is the total number of observed species, $a$ is the number of species counted once, and $b$ is the number of species counted twice. Other diversity estimates, such as the Shannon index, give similar patterns as species richness (data not shown).
The length and width $(\mu \mathrm{m})$ of each cyst in the database, not including processes, was extracted from literature sources, and the largest cross-sectional area $\left(\mu^{2}\right)$ of each cyst species was calculated based on appropriate geometric shapes (the detailed size data of each individual species and a list of references are provided in Table S1 in the supplement at www.intres.com/articles/suppl/m425p035_supp.pdf). The area of each cyst species was $\log _{10}$-transformed to achieve variance homogeneity. Median log area of the community in each sediment sample was calculated as the median size of the species present, not weighted 
by abundance to focus on the size changes of the cyst community caused by species turnover and how many species can be sustained within a particular environment (i.e. to avoid interference by changes in relative abundances of individual species). The 25th and 75th percentiles of the log area of each sample were also calculated. Twenty-four species for which we could not find size information were excluded from the analysis. These are generally rare species. In analyzing the relationships between cyst size structure and environmental factors, we discarded the samples in which the numerical abundances of the species without size information exceeded $25 \%$ of the total abundances ( 29 samples) and with species richness values $<3$ ( 6 samples). This resulted in a data set containing 1495 samples, comprising 78 species with size information, covering latitudes from $81^{\circ} \mathrm{N}$ to $66^{\circ} \mathrm{S}$.

Annual mean sea-surface $(0 \mathrm{~m})$ temperature $\left({ }^{\circ} \mathrm{C}\right)$ and nitrate and phosphate $\left(\mu \mathrm{mol}^{-1}\right)$ data for each sampling location were interpolated from the monthly climatology data downloaded from the World Ocean Atlas 2005 using the $k$-nearest-neighbor classification method in the R package class (Ripley 1996). We assumed that the cysts had not been horizontally transported far from where they grew originally as vegetative cells (see discussion in Marret \& Zonneveld 2003). Field evidence suggests that secondary transport generally has a minor, predominately local influence on cyst distribution, perhaps due to high sinking rates (Marret \& Zonneveld 2003). The spatial resolution of the temperature, nitrate, and phosphate climatology data is $1^{\circ}$ in latitude and longitude. Bathymetry data were obtained directly from the original data sources whenever possible. For samples without bathymetry (mostly in northern Atlantic and Arctic regions), the data were downloaded from the United States Naval Oceanographic Office. Spearman rank correlation was used throughout to restrict violation of normal distribution. The maps were drawn using Surfer 7.03 (Golden Software), with the global map (downloaded from www. aquarius.geomar.de) using Lambert azimuthal projection. The interpolations were conducted with the kriging or nearest-neighbor method in Surfer. Local polynomial regression fitting (loess) and the $95 \%$ confidential intervals were calculated using R (R Development Core Team 2009). As many variables are correlated with each other, partial correlations (Sokal \& Rohlf 1994) were used to investigate the relationships between one environmental variable and diversity/ size with a third controlled variable (i.e. to examine the correlations between residuals resulting from linear regressions of diversity/size with the third variable and of the target variable with the third variable, respectively).

\section{RESULTS}

\section{Latitudinal patterns in dinoflagellate cyst species richness and size structure}

There is a geographic structure in the species richness of dinoflagellate cysts, which varies from a minimum of 1 to a maximum of 101 (Fig. 1A). Average species richness increases from low values (mean \pm SE: $5.6 \pm 1.5)$ in polar regions to higher values $(22.1 \pm 0.6)$ at $\sim 40^{\circ}$ and varies between $16.9 \pm 0.8$ and $21.8 \pm$ 0.7 from $40^{\circ} \mathrm{S}$ to $40^{\circ} \mathrm{N}$ (Fig. 1B). Species richness is significantly negatively rank correlated with absolute latitude (Table 1). Richness is usually low throughout Arctic regions, while hotspots occur in the Celtic Sea, the Californian upwelling region, the Gulf of Guinea, and the sector of the Southern Ocean south of Australia (Fig. 1A). To compare with the diversity patterns of diatoms and coccolithophorids, we digitized the diversity data of diatoms and coccolithophorids from data reported by Cermeño et al. (2008a). While species richness of diatoms, coccolithophorids, and dinoflagellate cysts tends to be low in the Southern Ocean, there are significant differences in the latitudinal pattern in richness between the 3 groups (Fig. 1B). The latitudinal diversity pattern of diatoms largely follows nutrient availability (Cermeño et al. 2008a), but dinoflagellate cyst richness does not decrease with decreasing nutrient concentration in the tropics/subtropics (Fig. 1B).

The sizes of individual dinoflagellate cyst species range from 314.2 to $3959.2 \mu \mathrm{m}^{2}$ in area and exhibit a skewed log-normal frequency distribution (Fig. 2A). The median size of the dinoflagellate cyst community varies with latitude, but not in the same fashion as species richness. Median cell size of the dinoflagellate cyst communities is largest (log area mean \pm SE: $3.28 \pm 0.01 \log \mu \mathrm{m}^{2}$ ) in the highest southern latitudes $\left(66^{\circ} \mathrm{S}\right)$, decreases to $3.14 \log \mu \mathrm{m}^{2}$ from 66 to $36^{\circ} \mathrm{S}$, then increases from $36^{\circ} \mathrm{S}$ to $20^{\circ} \mathrm{N}(3.19 \pm 0.01 \mathrm{log}$ $\mu \mathrm{m}^{2}$ ), decreases to $3.12 \log \mu \mathrm{m}^{2}$ at $44^{\circ} \mathrm{N}$, and is relatively invariant to $80^{\circ} \mathrm{N}$ (Fig. 2C). The dramatic increase of median size in the Southern Ocean (south of $40^{\circ} \mathrm{S}$ ) is a combined result of the presence of a large endemic species, Selenopemphix antarctica, and the loss of small species (Table $1 ; 25$ th and 75th percentiles). The peak in median size at $20^{\circ} \mathrm{N}$ is a function of the specific ranges of the cosmopolitan species, such as Selenopemphix quanta, and endemic species, such as Bitectatodinium spongium, restricted to warm temperate and tropical waters. The most prominent geographic pattern in median size is an onshore-offshore gradient in the Californian upwelling, equatorial and southern Atlantic regions (Fig. 2B). 
Table 1. Spearman rank correlation and partial correlation coefficients among cyst richness, size, and environmental factors (For total data set, $\mathrm{n}=1532$ for richness and $\mathrm{n}=1495$ for size. For $\leq 13^{\circ} \mathrm{C}, \mathrm{n}=975$ for richness and 965 for size; for $>13^{\circ} \mathrm{C}, \mathrm{n}=557$ for richness and 530 for size). ILatl: absolute latitude; Temp.: annual mean temperature $\left({ }^{\circ} \mathrm{C}\right)_{i} \log \left[\mathrm{NO}_{3}\right]$ : $\log _{10}$ transformed nitrate concentration at $0 \mathrm{~m}\left(\mu \mathrm{mol} \mathrm{l}{ }^{-1}\right) ; \log \left[\mathrm{PO}_{4}\right]$ : $\log _{10}$ transformed phosphate concentration at $0 \mathrm{~m}\left(\mu \mathrm{mol}^{-1}\right)_{;}$Depth: water depth (m); Median: median size $\left(\log \mu \mathrm{m}^{2}\right) ; 25 \%$ Q: 25 th percentile size $\left(\log \mu \mathrm{m}^{2}\right) ; 75 \%$ Q: 75 th percentile size $\left(\log \mu \mathrm{m}^{2}\right)_{i}{ }^{* *}: \mathrm{p}<0.01,{ }^{*}: \mathrm{p}<0.05$

\begin{tabular}{|c|c|c|c|c|c|c|c|c|c|c|c|c|}
\hline & \multirow{2}{*}{ Richness } & \multicolumn{3}{|c|}{ - Total data set - } & \multicolumn{4}{|c|}{$-\leq 13^{\circ} \mathrm{C}$} & \multirow[b]{2}{*}{ Richness } & \multicolumn{3}{|c|}{$->13^{\circ} \mathrm{C}$} \\
\hline & & Median & $25 \% \mathrm{Q}$ & $75 \% \mathrm{Q}$ & Richness & Median & $25 \% \mathrm{Q}$ & $75 \% \mathrm{Q}$ & & Median & $25 \% Q$ & $75 \% Q$ \\
\hline \multicolumn{13}{|c|}{ Spearman rank correlation } \\
\hline |Lat| & $-0.52^{* *}$ & $-0.11^{* *}$ & $0.29^{* *}$ & $-0.29^{* *}$ & $-0.54^{* *}$ & 0.01 & $0.25^{* *}$ & $-0.29^{* *}$ & $0.14^{* *}$ & $-0.25^{* *}$ & $-0.15^{* *}$ & * 0.01 \\
\hline Temp. & $0.57^{* *}$ & $0.14^{* *}$ & $-0.26^{* *}$ & $0.35^{* *}$ & $0.63^{* *}$ & $0.11^{* *}$ & $-0.19^{* *}$ & $0.43^{* *}$ & -0.08 & $0.22 * *$ & $0.23^{* *}$ & -0.06 \\
\hline $\log \left[\mathrm{NO}_{3}\right]$ & $-0.13^{* *}$ & 0.03 & $0.09^{* *}$ & $0.16^{* *}$ & $0.15^{* *}$ & $0.16^{* *}$ & -0.02 & $0.39^{* *}$ & 0 & -0.03 & -0.07 & $0.10^{*}$ \\
\hline $\log \left[\mathrm{PO}_{4}\right]$ & $-0.17^{* *}$ & 0.01 & $0.09^{* *}$ & $0.06^{* *}$ & $0.12^{* *}$ & $0.07^{*}$ & -0.05 & $0.18^{* *}$ & $-0.09^{*}$ & 0.06 & -0.02 & $0.20^{* *}$ \\
\hline Depth & $0.23^{* *}$ & $-0.15^{* *}$ & $-0.34^{* *}$ & $0.15^{* *}$ & $0.16^{* *}$ & -0.06 & $-0.21^{* *}$ & $0.24^{* *}$ & 0.01 & $-0.47^{* *}$ & $-0.40^{* *}$ & $-0.35^{* *}$ \\
\hline \multicolumn{13}{|c|}{ Partial correlation (holding Temp. constant) } \\
\hline ILatl & $0.06^{*}$ & -0.01 & $0.09^{* *}$ & $0.06^{*}$ & -0.02 & 0.06 & $0.16^{* *}$ & $0.09^{*}$ & $0.10^{*}$ & -0.04 & 0.06 & -0.03 \\
\hline $\log \left[\mathrm{NO}_{3}\right]$ & $0.11^{* *}$ & $0.16^{* *}$ & 0.03 & $0.36^{* *}$ & 0 & $0.17^{* *}$ & 0.06 & $0.35^{* *}$ & -0.05 & $0.24^{* *}$ & $0.14^{* *}$ & * $0.16^{* *}$ \\
\hline $\log \left[\mathrm{PO}_{4}\right]$ & 0.04 & $0.15^{* *}$ & 0.02 & $0.26^{* *}$ & -0.05 & $0.15^{* *}$ & 0 & $0.19^{* *}$ & $-0.11^{*}$ & $0.21^{* *}$ & $0.15^{* *}$ & * $0.19^{* *}$ \\
\hline Depth & -0.03 & $-0.25^{* *}$ & $-0.28^{* *}$ & 0.01 & -0.06 & 0.01 & $-0.17^{* *}$ & $0.20^{* *}$ & -0.06 & $-0.51^{* *}$ & $-0.39^{* *}$ & $-0.36^{* *}$ \\
\hline
\end{tabular}
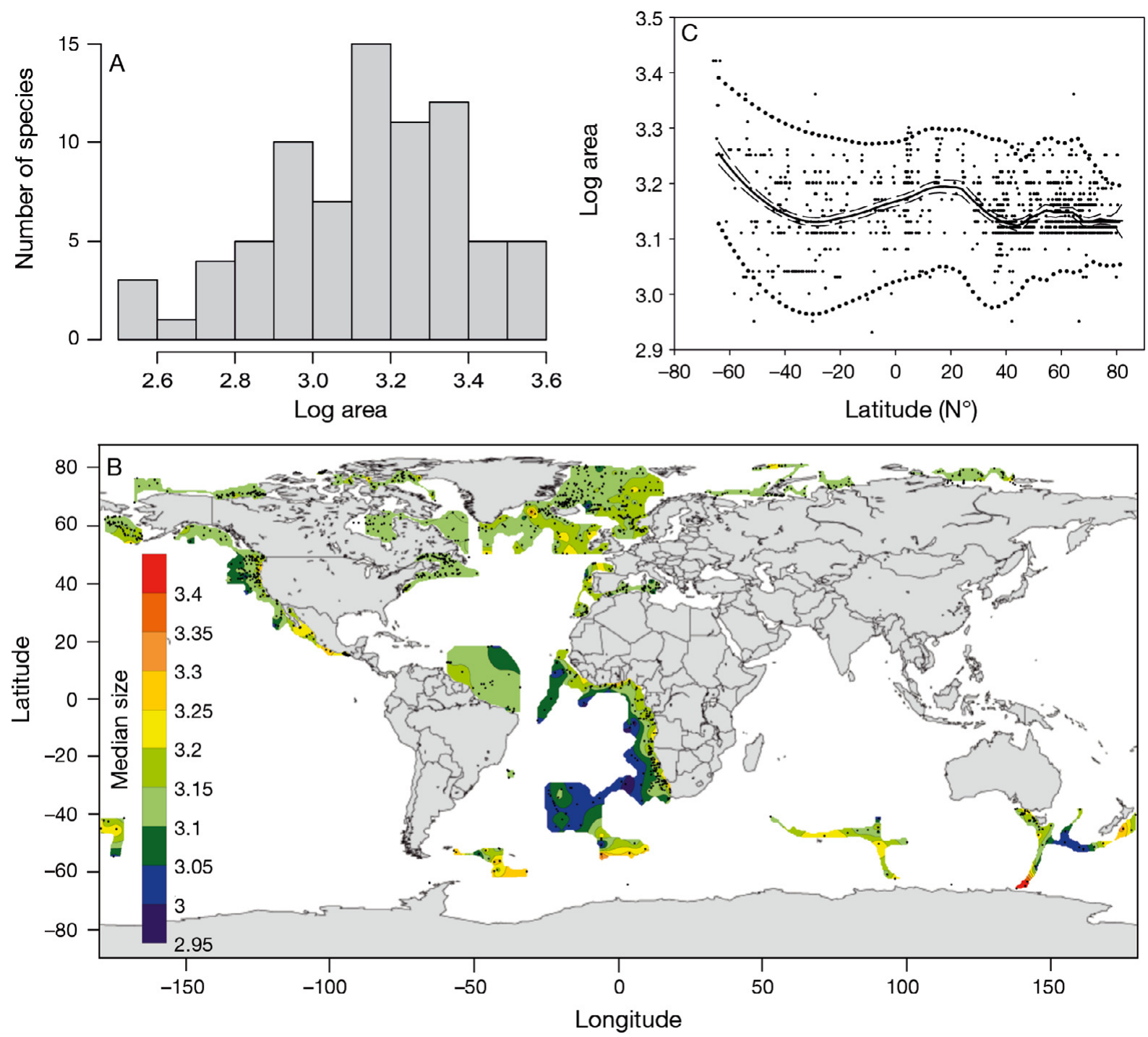

Fig. 2. (A) Frequency distribution histogram of dinoflagellate cyst size (log area, $\mu^{2}$ ). (B) Contour maps of the median size (log $\mu \mathrm{m}^{2}$ ) of dinoflagellate cyst communities. (C) Median cyst size $\left(\log \mu \mathrm{m}^{2}\right.$ ) versus latitude, with loess smoothing line (solid line) and $95 \%$ confidence intervals (dashed lines) shown. Dotted lines: 25th and 75th percentile sizes 


\section{Environmental controls on dinoflagellate cyst species richness and size}

Temperature and latitude appear to be the most important environmental factors affecting richness. Dinoflagellate cyst species richness is positively rank correlated with annual mean temperature (Table 1, Fig. 3A), negatively rank correlated with nitrate $\left(\log \left[\mathrm{NO}_{3}\right]\right)$ and phosphate $\left(\log \left[\mathrm{PO}_{4}\right]\right)$, and positively correlated with water depth (Table 1, Fig. 3B, C). Temperature accounts for most of the correlation between richness and latitude. The effect of temperature on cyst richness is most pronounced in cold waters $<13^{\circ} \mathrm{C}$ (Table 1, Fig. 3A). In contrast, macronutrient concentration and depth are only marginally correlated with richness. If temperature is held constant, richness is weakly positively correlated with $\log \left[\mathrm{NO}_{3}\right]$ and $\log$ $\left[\mathrm{PO}_{4}\right]$, but not correlated with depth (Table 1).

Environmental correlates for size structure differ from species richness. Increasing temperature tends to relate to an increase in the size range (maximum to minimum size) of the dinoflagellate cysts within samples, increasing 2.5 -fold from -1.4 to $28.5^{\circ} \mathrm{C}$. The 75 th percentile is positively rank correlated with temperature, while the 25th percentile is negatively correlated with temperature (Table 1). At higher temperatures, the higher species richness allows for a higher variability in size (increase in size range) among species. In contrast, the median size of the dinoflagellate cyst assemblages is not highly correlated with temperature when temperature is $<20^{\circ} \mathrm{C}$, but does increase with temperature $>20^{\circ} \mathrm{C}$ (Fig. 3D).

Instead of temperature, water depth appears to be the strongest correlate for median cyst size in warm regions, particularly in the southern Atlantic and off western California (Table 1, Fig. 2B). Loess average median size generally decreases with water depth, and increasing depth is always associated with a decrease in the size of the 25th percentile (Table 1, Fig. 3F). Although macronutrient concentrations in the euphotic zone often tend to be lower in deeper waters, the correlation between depth and cyst size is much stronger than that between nutrient concentration and cyst size (Table 1). The effect of macronutrient concentrations on median size is most pronounced in the Southern Ocean, where larger median size coincides with higher nitrate concentrations (Fig. 3E). Overall, the effect of macronutrient concentrations on size is weakly positive and most evident for the 75th percentile (Table 1, Fig. 3E).

\section{Relationship between cyst species richness and size}

At low richness, the median size can range from small to large, while, at high richness, the median size converges to a medium value (Fig. 4). Overall, richness is only weakly correlated with median size (Spearman $\mathrm{r}=0.10, \mathrm{p}<0.001, \mathrm{n}=1495)$. Temperature appears to be the major factor causing the weak correlation. When factoring in temperature using partial correlation, the relationship between richness and median size disappears (Table 1).

\section{DISCUSSION}

Large-scale patterns of biodiversity and size on the community level are, in part, an emergent pattern caused by the collective behaviors of each individual species responding to external physical, chemical, and biological conditions. Increased knowledge of the biogeographic patterns of different plankton groups will clarify the contribution of specific physiological and other mechanisms that control community structure. Bridging the gap between our knowledge on organismal physiology and macroscopic distributional patterns is essential to improve our ability to understand and predict the community structure under changing environmental and climatic conditions (Brown 1995, Irwin et al. 2006, Finkel et al. 2010). The correlates between species diversity and average size of dinoflagellate cysts and environmental variables are not necessarily direct indications of cause-effect relationships, but should reveal potential deterministic factors that control plankton community structure or co-vary with key drivers.

\section{Phytoplankton functional groups - biogeography and environmental co-variables}

The latitudinal diversity patterns of the phytoplankton groups are consistent with the recent model predictions in which phytoplankton diversity is predominantly regulated by environmental and ecophysiological processes, such as competition and lateral dispersal (Barton et al. 2010). In sub-polar regions with highly variable nutrient supplies, opportunistic species with higher growth rates are favored, resulting in lower species richness, while in stable subtropical and tropical regions, more species are able to coexist (Barton et al. 2010). These predictions and model assumptions can be further tested by analyzing the biogeographic distributions of plankton functional groups and quantifying the photosynthetic and growth responses of typical plankton species from tropical and polar sites.

Fundamental eco-physiological differences between different plankton groups may explain the differences in their biogeographic distribution and, in particular, 

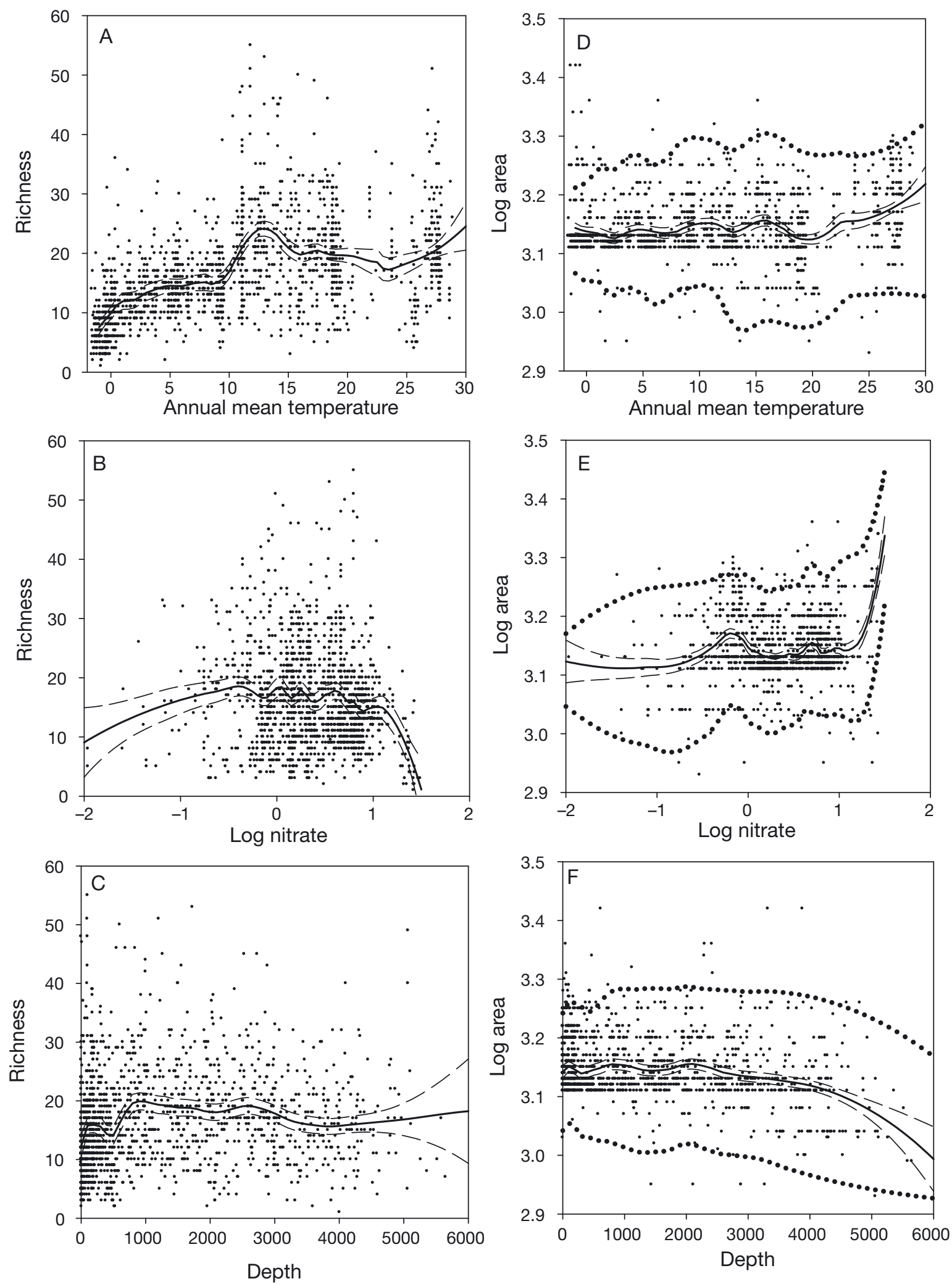

Fig. 3. Richness versus (A) temperature $\left({ }^{\circ} \mathrm{C}\right)$, (B) $\log$ nitrate $\left(\mu \mathrm{mol} \mathrm{l}^{-1}\right)$, and $(\mathrm{C})$ depth $(\mathrm{m})$. Median cyst size $\left(\mathrm{log} \mu \mathrm{m}^{2}\right)$ versus $(\mathrm{D})$ temperature $\left({ }^{\circ} \mathrm{C}\right),(\mathrm{E}) \log$ nitrate $\left(\mu \mathrm{mol} \mathrm{l}^{-1}\right)$, and $(\mathrm{F})$ depth $(\mathrm{m})$. Loess smoothing lines (solid lines) and $95 \%$ confidence intervals (dashed lines) are also shown. Dotted lines: loess smoothing lines of 25th and 75th percentiles. In Panels A to C, 2 data points with richness $>60$ are not shown, but were included in the calculation 


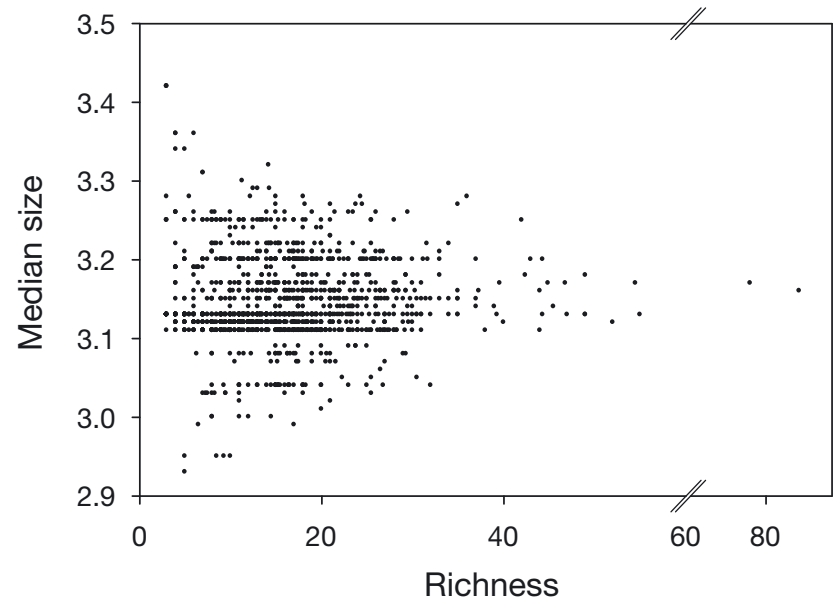

Fig. 4. Median size of dinoflagellate cyst communities $\left(\log \mu \mathrm{m}^{2}\right)$ versus richness

the differences in their diversity gradients with latitude. Post-depositional lateral transport of cysts from these studies is generally on local scales (Marret \& Zonneveld 2003), and there is no evidence that they played a dominant role in determining the large-scale biogeographic patterns in the dinoflagellate cyst diversity observed. The relative abundance and diversity of a taxonomic group is expected to be regulated by environmental conditions that influence growth and survival. Dinoflagellate cyst species richness, which we assume reflects a subset of the diversity of living dinoflagellates, is more highly correlated with seasurface temperature than latitude, and, when temperature is held constant, latitude is a minor correlate of community richness (Table 1). One interpretation of the data is that warm, stratified, low-latitude regions stimulate more dinoflagellate species to produce cysts, leading to higher cyst species richness. Favorable temperature, light, and nutrient conditions may trigger sexuality and encystment in dinoflagellates in situ (Anderson et al. 1985a, Kremp \& Heiskanen 1999). We propose that temperature is such a good correlate of dinoflagellate richness because it is an excellent correlate of water-column stability. Dinoflagellates are well known for their inferior ability to compete in turbulent waters (Thomas \& Gibson 1990, Peters \& Marrasé 2000). Beyond a critical threshold of turbulence, dinoflagellates may stop dividing or lose their flagella, and, as a result, their growth rates can be severely inhibited by small-scale turbulence even for short periods of time (Gibson \& Thomas 1995). The inability of most cyst-forming dinoflagellates to thrive in turbulent environments is consistent with decreasing levels of species richness in assemblages poleward of both $40^{\circ} \mathrm{N}$ and $40^{\circ} \mathrm{S}$ (Fig. 1) and the high positive correlation between dinoflagellate cyst richness and sea-surface temperature, especially at $<13^{\circ} \mathrm{C}$ (Table 1). Decreases in sea-surface temperatures $<13^{\circ} \mathrm{C}$ are likely associated with increasing levels of surface mixing and turbulence. The lower correlation between richness and sea-surface temperatures $>13^{\circ} \mathrm{C}$ is likely due to an uncoupling between water-column stability and increasing sea-surface temperatures above this threshold temperature.

The weak correlations between surface macronutrient concentrations and dinoflagellate cyst species richness are consistent with the observation that many dinoflagellates are poor competitors for inorganic nutrients (Litchman 2007). Many dinoflagellate species are mixotrophs or heterotrophs, which may reduce their inorganic nutrient requirements and therefore their need for competitive inorganic nutrient uptake rates (Margalef 1978, Smayda 1997, Litchman 2007). As a result of these collective features, dinoflagellates are expected to attain greater biomass and highest diversities in warm, stratified, oligotrophic regions (Margalef 1978), as confirmed in the present study (Fig. 1) and observed in the fossil record (Fensome et al. 1996, Finkel et al. 2007).

In contrast, diatoms thrive in well-mixed water columns, have high maximal uptake rates for inorganic nutrients and high growth rates relative to other taxonomic groups (Irwin et al. 2006), and often attain great biomass and high diversity in well-mixed, unstable waters (Li 2002, Cermeño et al. 2008a). Turbulence may help replenish the nutrient-depleted diffusive layer around immotile diatom cells, improving growth rates (Thomas \& Gibson 1990, Kiørboe 1993, Peters \& Marrasé 2000), and mixing minimizes sinking loss of the dense siliceous diatoms out of the euphotic zone. As a group, diatoms can be viewed as opportunist, higher nutrient 'rstrategy' organisms, and dinoflagellates can be viewed as gleaner, lower nutrient, 'K-strategy' organisms (Margalef 1978, Litchman 2007). Other functional groups have different ecophysiological trade-offs that place them intermediately along the r- to K-strategy continuum. Coccolithophorid genera, such as Emiliania and Gephyrocapsa, have maximum growth rates (for a given size) intermediate between diatoms and dinoflagellates (Irwin et al. 2006), and often bloom under high-light and low-nutrient conditions, as the upper water column stratifies and diatom blooms are in decline (Iglesias-Rodríguez et al. 2002), consistent with the correspondence of their peak diversity with the diatoms between 35 and $55^{\circ} \mathrm{S}$ (Fig. 1B). Physiological work indicates that some species are well adapted to high light, even under nitrate starvation (Nanninga \& Tyrrell 1996, Litchman 2007 , Loebl et al. 2010). Their eco-physiological adaptations to a stratifying water column may account for some of the similarities in their biogeographic pattern in species diversity with the organic dinoflagellates cysts (Fig. 1B; Cermeño et al. 2008a). 


\section{Biogeography of community size-structure and environmental co-variables}

Size is an important attribute of all living organisms, affecting resource and habitat requirements, metabolic rate, generation time, and predation risk (Brown et al. 2004). In phytoplankton, cell size influences, and, therefore, community size structure is influenced by, light acquisition, nutrient requirements, nutrient diffusion and active uptake parameters, metabolic rate, sinking rates, and grazing susceptibility (Mei et al. 2009, Finkel et al. 2010). Organism size may also be an important factor determining the strength of the latitudinal richness gradient (Hillebrand \& Azovsky 2001, Finlay 2002, Hillebrand 2004). In the case of the dinoflagellate cyst assemblages, the maximum potential size range of the assemblage is positively correlated with the richness of the assemblage, but the median size is independent of species richness (Fig. 4).

In marine systems, the proportion of large phytoplankton in an assemblage tends to increase as standing stock chlorophyll concentration, primary productivity, or nutrient availability increases (Chisholm 1992, Li 2002, Chen \& Liu 2010). This suggests that richness and average size and the higher size quartiles should increase with nutrient concentration as nutrient supply relieves larger cells from nutrient limitation (Irwin et al. 2006), if grazing pressure does not bias the size distribution (Kiørboe 1993, Thingstad et al. 2005) and light does not become limiting (Finkel et al. 2009). As temperature and nutrient levels are usually negatively correlated (Kamykowski 1987, Steinhoff et al. 2010), small phytoplankton tend to dominate communities in warm, oligotrophic waters, while large cells become increasingly dominant in cold, nutrient-rich waters (Irwin et al. 2006, Daufresne et al. 2009, Kostadinov et al. 2009, Chen \& Liu 2010).

In contrast, median dinoflagellate cyst size is negatively correlated with nutrient concentration. It is not that larger dinoflagellates cannot thrive under higher nutrient conditions, but that their growth and survival is inhibited under well-mixed, colder, turbulent waters that are often characterized by higher nutrient concentrations. At any given sea-surface temperature, there is a significant positive correlation between nitrate and phosphate concentrations in surface waters and the median size of the dinoflagellate cyst community, especially the larger cells (75th percentile) (Table 1). While phytoplankton communities, including diatoms, often exhibit an increase in average size and diversity in well-mixed, high-nutrient, high-chlorophyll waters, dinoflagellate assemblages are more likely to exhibit larger sizes in stable water columns with warmer sea surface temperatures and with intermediate to lower nutrient concentrations (Table 1, Fig. 2). In the
Southern Hemisphere the increase in cyst size towards higher latitudes is predominantly due to an increase in the dominance of the large endemic species Selenopemphix antarctica in the assemblages. The unique physiological adaptations of this species to the cold and turbulent Southern Ocean and its motile affinity are largely unknown (Marret \& Zonneveld 2003).

There is a significant decrease in the size of dinoflagellate cysts moving from onshore to offshore waters in the eastern Pacific and equatorial and southern Atlantic (Table 1, Figs. 2B \& 3F), which may be related to the high sinking rates of the larger dinoflagellate cysts (Anderson et al. 1985b), secondary transport by offshore currents, or patterns in grazing and microbial degradation. Sinking velocity estimates for dinoflagellate cysts are limited, but the data available indicate that dinoflagellate cysts may sink much faster than vegetative dinoflagellate cells owing to higher cellular densities (Anderson et al. 1985b). As a result, it may be relatively challenging for large cysts to maintain sizable upper mixed-layer populations in deep offshore waters (Table 1, Fig. 3F). As well as slower sinking velocities, smaller dinoflagellate cyst species may have a growth advantage over larger species in offshore, lower nutrient environments. In addition, higher grazing mortality or selective microbial degradation of smaller cysts in onshore regions might contribute to a reduction in the diversity of smaller species (Persson 2000), perhaps contributing to the strong increase in the 25th percentile of cyst size with decreasing water depth (Table 1, Fig. 3F).

\section{SUMMARY}

Species richness of organic dinoflagellate cyst communities is positively correlated with sea-surface temperature, especially in cooler waters, likely due to a suite of physiological adaptations to stable water columns. Macronutrient concentration is a positive correlate for species richness, but is secondary to watercolumn stability. Water-column depth and nutrient concentration are more important correlates than temperature for the size structure of dinoflagellate cyst assemblages. Smaller cells become an increasingly large component of dinoflagellate cyst communities away from the coast. Significant correlations between environmental conditions, temperature, nutrient concentrations, water depth, and the richness and size structure of the dinoflagellate cyst communities differ from other phytoplankton groups. These differences indicate that the unique physiological features of dinoflagellate cyst communities play an important role in determining the biogeographic patterns in species richness and size structure. 
Acknowledgements. We thank J. Sebbo and D. Blanchette for their contributions to this work. This work was supported by NSERC Discovery (Z.V.F and A.J.I) and a ACENET PostDoctoral Fellowship Award (B.C.).

\section{LITERATURE CITED}

Allen AP, Gillooly JF (2006) Assessing latitudinal gradients in speciation rates and biodiversity at the global scale. Ecol Lett 9:947-954

Anderson DM, Wall D (1978) Potential importance of benthic cysts of Gonyaulax tamarensis and G. excavate in initiating toxic dinoflagellate blooms. J Phycol 14:224-234

Anderson DM, Coats DW, Tyler MA (1985a) Encystment of the dinoflagellate Gyrodinium uncatenum: temperature and nutrient effects. J Phycol 21:200-206

Anderson DM, Lively JJ, Reardon EM, Price CA (1985b) Sinking characteristics of dinoflagellate cysts. Limnol Oceanogr 30:1000-1009

> Azam F, Fenchel T, Field JG, Gray JS, Meyer-Reil LA, Thingstad F (1983) The ecological role of water-column microbes in the sea. Mar Ecol Prog Ser 10:257-263

Barton AD, Dutkiewicz S, Flierl G, Bragg J, Follows MJ (2010) Patterns of diversity in marine phytoplankton. Science 327:1509-1511

Brown JH (1995) Macroecology. University of Chicago Press, Chicago, IL

Brown JH, Gillooly JF, Allen AP, Savage VM, West GB (2004) Toward a metabolic theory of ecology. Ecology 85: 1771-1789

> Cermeño P, Dutkiewicz S, Harris RP, Follows M, Schofield O, Falkowski PG (2008a) The role of nutricline depth in regulating the ocean carbon cycle. Proc Natl Acad Sci USA 105:20344-20349

Cermeño P, Marañon E, Harbour D, Figueiras FG and others (2008b) Resource levels, allometric scaling of population abundance, and marine phytoplankton diversity. Limnol Oceanogr 53:312-318

Chen B, Liu H (2010) Relationships between phytoplankton growth and cell size in surface oceans: interactive effects of temperature, nutrients, and grazing. Limnol Oceanogr 55:965-972

Chisholm SW (1992) Phytoplankton size. In: Falkowski PG, Woodhead AD (eds) Primary productivity and biogeochemical cycles in the sea. Plenum Press, New York, NY, p 213-237

Colwell RK (2005) EstimateS: statistical estimation of species richness and shared species from samples, Version 7.5. User's guide and application. Available at: http://purl.oclc. org/estimates

Dale B, Dale AL, Jansen JHF (2002) Dinoflagellate cysts as environmental indicators in surface sediments from the Congo deep-sea fan and adjacent regions. Palaeogeogr Palaeoclimatol Palaeoecol 185:309-338

Daufresne M, Lengfellner K, Sommer U (2009) Global warming benefits the small in aquatic ecosystems. Proc Natl Acad Sci USA 106:12788-12793

Dolan JR, Lemee R, Gasparini S, Mousseau L, Heyndrickx C (2006) Probing diversity in the plankton: using patterns in tintinnids (planktonic marine ciliates) to identify mechanisms. Hydrobiologia 555:143-157

Esper O, Zonneveld KAF (2002) Distribution of organicwalled dinoflagellate cysts in surface sediments of the Southern Ocean (eastern Atlantic sector) between the Subtropical Front and the Weddell Gyre. Mar Micropaleontol 46:177-208
Fensome RA, MacRae RA, Williams GL (1996) Dinoflagellate evolution and diversity through time. Sci Rev Bedford Inst Oceanogr 1994/1995:45-50

> Finkel ZV, Sebbo J, Feist-Burkhardt S, Irwin AJ and others (2007) A universal driver of macroevolutionary change in the size of marine phytoplankton over the Cenozoic. Proc Natl Acad Sci USA 104:20416-20420

Finkel ZV, Vaillancourt CJ, Irwin AJ, Reavie ED, Smol JP (2009) Environmental control of diatom community size structure varies across aquatic ecosystems. Proc Biol Sci 276:1627-1634

Finkel ZV, Beardall J, Flynn KJ, Quigg A, Rees TAV, Raven JA (2010) Phytoplankton in a changing world: cell size and elemental stoichiometry. J Plankton Res 32:119-137

Finlay BJ (2002) Global dispersal of free-living microbial eukaryote species. Science 296:1061-1063

Fuhrman JA, Steele JA, Hewson I, Schwalbach MS, Brown MV, Green JL, Brown JH (2008) A latitudinal diversity gradient in planktonic marine bacteria. Proc Natl Acad Sci USA 105:7774-7778

Gaston KJ, Blackburn TM (2000) Pattern and process in macroecology. Blackwell Science, Oxford

> Gibson GH, Thomas WH (1995) Effects of turbulence intermittency on growth inhibition of a red tide dinoflagellate, Gonyaulax polyedra Stein. J Geophys Res 100: 24841-24846

Hansen PJ (1992) Prey size selection, feeding rates and growth dynamics of heterotrophic dinoflagellates with special emphasis on Gyrodinium spirale. Mar Biol 114: 327-334

Harland R, Pudsey CJ, Howe JA, Fitzpatrick MEJ (1998) Recent dinoflagellate cysts in a transect from the Falklands through to the Weddell Sea, Antarctic. Palaeontology 41:1093-1131

Hillebrand H (2004) Strength, slope and variability of marine latitudinal gradients. Mar Ecol Prog Ser 273:251-267

Hillebrand H, Azovsky AI (2001) Body size determines the strength of the latitudinal diversity gradient. Ecography 24:251-256

Holzwarth U, Esper O, Zonneveld KAE (2007) Distribution of organic-walled dinoflagellate cysts in the shelf surface sediments of the Benguela upwelling system in relationship to environmental conditions. Mar Micropaleontol 64: 91-119

> Hutchinson GE (1959) Homage to Santa Rosalia or why are there so many kinds of animals? Am Nat 93:145-159

> Iglesias-Rodríguez MD, Brown CW, Doney SC, Kleypas J and others (2002) Representing key phytoplankton functional groups in ocean carbon cycle models: coccolithophorids. Global Biogeochem Cycles 16:1100-1119 doi:10.1029/ 2001GB001454

> Irwin AJ, Finkel ZV, Schofield OME, Falkowski PG (2006) Scaling-up from nutrient physiology to the size-structure of phytoplankton communities. J Plankton Res 28:459-471

> Kamykowski D (1987) A preliminary biophysical model of relationship between temperature and plant nutrients in the upper ocean. Deep Sea Res I 34:1067-1079

Kiørboe T (1993) Turbulence, phytoplankton cell size, and the structure of pelagic food webs. Adv Mar Biol 29:1-72

Kostadinov TS, Siegel DA, Maritorena S (2009) Retrieval of the particle size distribution from satellite ocean color observations. J Geophys Res 114:C09015. doi:10.1029/ 2009JC005303

- Kremp A, Heiskanen AS (1999) Sexuality and cyst formation of the spring-bloom dinoflagellate Scrippsiella hangoei in the coastal northern Baltic Sea. Mar Biol 134:771-777

Lewis J, Harris ASD, Jones KJ, Edmonds RL (1999) Long-term 
survival of marine planktonic diatoms and dinoflagellates in stored sediment samples. J Plankton Res 21:343-354

Li WKW (2002) Macroecological patterns of phytoplankton in the northwestern North Atlantic Ocean. Nature 419: $154-157$

Litchman E (2007) Resource competition and the ecological success of phytoplankton. In: Falkowski PG, Knoll AH (eds) Evolution of primary producers in the sea. Elsevier, Amsterdam, p 351-375

Loebl M, Cockshutt AM, Campbell DA, Finkel ZV (2010) Physiological basis for high resistance to photoinhibition under nitrogen depletion in Emiliania huxleyi. Limnol Oceanogr 55:2150-2160

Margalef R (1978) Life-forms of phytoplankton as survival alternatives in an unstable environment. Oceanol Acta 1: 493-509

Marret F (1994) Distribution of dinoflagellate cysts in recent marine sediments from the east Equatorial Atlantic (Gulf of Guinea). Rev Palaeobot Palynol 84:1-22

Marret F, de Vernal A (1997) Dinoflagellate cyst distribution in surface sediments of the southern Indian Ocean. Mar Micropaleontol 29:367-392

Marret F, Zonneveld KAF (2003) Atlas of modern organicwalled dinoflagellate cyst distribution. Rev Palaeobot Palynol 125:1-200

Mei ZP, Finkel ZV, Irwin AJ (2009) Light and nutrient availability affect the size-scaling of growth in phytoplankton. J Theor Biol 259:582-588

> Nanninga HJ, Tyrrell T (1996) Importance of light for the formation of algal blooms by Emiliania huxleyi. Mar Ecol Prog Ser 136:195-203

> Persson A (2000) Possible predation of cysts - A gap in the knowledge of dinoflagellate ecology? J Plankton Res 22: 803-809

Peters F, Marrasé C (2000) Effects of turbulence on plankton: an overview of experimental evidence and some theoretical considerations. Mar Ecol Prog Ser 205:291-306

R Development Core Team (2009) R: a language and environment for statistical computing. R Foundation for Statistical Computing, Vienna. Available at: www.R-project.org

Radi T, de Vernal A (2008) Dinocysts as proxy of primary productivity in mid-high latitudes of the Northern Hemi-

Editorial responsibility: Hans Heinrich Janssen,

Oldendorf/Luhe, Germany sphere. Mar Micropaleontol 68:84-114

Ripley BD (1996) Pattern recognition and neural networks. Cambridge University Press, Cambridge

Rosenzweig ML (1995) Species diversity in space and time. Cambridge University Press, New York, NY

Sherr EB, Sherr BF (2007) Heterotrophic dinoflagellates: a significant component of microzooplankton biomass and major grazers of diatoms in the sea. Mar Ecol Prog Ser 352:187-197

Smayda TJ (1997) Harmful algal blooms: their ecophysiology and general relevance to phytoplankton blooms in the sea. Limnol Oceanogr 42:1137-1153

> Smetacek VS (1985) Role of sinking in diatom life-history cycles: ecological, evolutionary, and geological significance. Mar Biol 84:239-251

Sokal RR, Rohlf FJ (1994) Biometry: the principles and practice of statistics in biological research. W. H. Freeman, New York, NY

Steinhoff T, Friedrich T, Hartman SE, Oschlies A, Wallace DWR, Körtzinger A (2010) Estimating mixed layer nitrate in the North Atlantic Ocean. Biogeosciences 7:795-807

Taylor FJR (1987) (ed) The biology of dinoflagellates, Vol 21. Blackwell Scientific Publications, Oxford

Thingstad TF, Ovreas L, Egge JK, Lovdal T, Heldal M (2005) Use of non-limiting substrates to increase size: a generic strategy to simultaneously optimize uptake and minimize predation in pelagic osmotrophs? Ecol Lett 8:675-682

- Thomas WH, Gibson CH (1990) Effects of small-scale turbulence on microalgae. J Appl Phycol 2:71-77

> Vink A, Zonneveld KAF, Willems H (2000) Organic-walled dinoflagellate cysts in western equatorial Atlantic surface sediments: distributions and their relation to environment. Rev Palaeobot Palynol 112:247-286

> Woodd-Walker RS, Ward P, Clarke A (2002) Large-scale patterns in diversity and community structure of surface water copepods from the Atlantic Ocean. Mar Ecol Prog Ser 236:189-203

Zonneveld KAF, Hoek RP, Brinkhuis H, Willems H (2001) Geographic distributions of organic-walled dinoflagellate cysts in surficial sediments of the Benguela upwelling region and their relationship to upper ocean conditions. Prog Oceanogr 48:25-72

Submitted: April 26, 2010; Accepted: December 8, 2010 Proofs received from author(s): February 24, 2011 